\title{
Communist Extremists, Islamic Supremacists, and Narco-Terrorists: A Forensic Sociological Threat Analysis of Radicalization within the Federative Republic of Brazil
}

\author{
Knowles GJ \\ Administration of Justice and Sociology, Honolulu Community College, University of Hawaii, Honolulu, Hawaii, \\ USA
}

${ }^{*}$ Corresponding author: Knowles GJ, Administration of Justice and Sociology, Honolulu Community College, University of Hawaii, Honolulu, Hawaii, USA, E-mail: GordonKnow@aol.com

Citation: Knowles GJ (2018) Forensic Sociological Threat Analysis of Radicalization within the Federative Republic of Brazil. J Forensic Sci Criminol 6(1): 101

Received Date: November 12, 2017 Accepted Date: March 8, 2018 Published Date: March 9, 2018

\begin{abstract}
This article presents a human terrain analysis of the Islamic radicalization occurring in Latin America and the infiltration of the Al-Qaeda terrorist network into the country of Brazil. The study used sociological investigative research methods conducted in Brazil, extensive ethnographic interviews collected in the major Brazilian cities of Sao Paulo and Rio de Janeiro, and intensive Brazilian Portuguese language immersion. The ethnographic research techniques examined the social, political, religious, and linguistic structures to gain an understanding of how Al-Qaeda operatives have established an operational base in Brazil. The study provides an early warning sociological intelligence assessment of the threat of radical Islam in Latin America. Specifically, the findings indicate an extremist Islamic social movement and Al-Qaeda terrorist theology is present in Brazil. The research findings indicate the Al-Qaeda terrorist group is conducting terrorist training, recruiting new operatives, radicalizing Islamic moderates and indoctrinating fanatical converts, as well as fabricating counterfeit merchandise to fund global terrorism operations. In closing, the overall sociological analysis indicates that Al-Qaeda in Brazil $(\mathrm{AQB})$ is implementing plans to execute a new attack on the United States, and conceivably against the host country of Brazil.
\end{abstract}

Keywords: Al-Qaeda in Brazil; Islamic Radicalization; Cults; Marxist-Islam; Religious Extremists

\section{The War on Terror}

At 8:45 a.m. on September $11^{\text {th }}, 2001$ the New York World Trade Center buildings begin to collapse from a terrorist skyjacking that propelled two United States private airliners into an icon of American economic success promoted by the ideologies of democracy, capitalism, and Christianity. Within the next few minutes, another airliner smashes into the worldwide military headquarters of the United States known as the Pentagon. Finally, a fourth airliner, destined for the White House, was unsuccessful and crashed in a field before reaching its intended target in Washington, D.C. Beyond any doubt, and from the highest levels of government, the United States was unaware, unprepared, and unable to prevent these attacks [1]. Obscure and fragmented details quickly emerged that the nineteen terrorists who skyjacked all four airliners were members of an elite terrorist group known as "Al-Qaeda" or "the base" in Arabic. The group was led by a misguided religious zealot, but extremely intelligent Islamic radical named Osama Bin Laden from the Middle Eastern country of Saudi Arabia [2].

Immediately after the attack, the United States took aggressive actions to hunt down and destroy Al-Qaeda, its leadership, its affiliates, and sanction any country that harbored them. Specifically, these actions included the United States invasion of Afghanistan in 2001, the defeat of Al-Qaeda in Iraq (AQI) forces in Baghdad culminating with the assassination of their Jordanian militant leader Abu-Musab al-Zarqawi in 2006, and the assassination of Saudi Arabian millionaire Osama bin Laden in Pakistan in 2011[3]. To date, the United States continues to leave "no stone unturned" to destroy any Al-Qaeda presence.

The United States continuous political influence and military presence in Iraq and Afghanistan have destroyed the Al-Qaeda strongholds in these countries. Additionally, the assassinations of chief Al-Qaeda operatives such as bin Laden and Al-Zarqawi have decimated the terrorist organizations leadership. However, on June 16 ${ }^{\text {th }}, 2011-$ Egyptian born Ayman al Zawahiri assumed command of the Al-Qaeda terrorist network and began to redirect Al-Qaeda's future operations [4]. On the 2013 anniversary of September $11^{\text {th }}$, via world-wide Internet broadcast, Al Zawahiri restated Al-Qaeda's commitment to destroy the United States. Specifically, Al Zawahiri called on Al-Qaeda operatives to "land a large strike" on the United States. This essay examines Al-Qaeda's 
existence, expansion, and operations in Brazil and the geographical, political, and social reasons that enable this terrorist network to maintain a base of operations in Latin America's largest country. This research provides actual in-country informant based information, content analysis of host country media sources, investigation of Al-Qaeda tradecraft, and the terrorist group's tactics, techniques, and procedures in the country of Brazil.

\section{The Sociology of Terrorism}

For the global intelligence agency audience, the intent of this research is to provide a concise area study and ethnographic terrain analysis and sociological intelligence assessment of the emerging Al-Qaeda in Latin America, but specifically a country study of the Al-Qaeda terrorist presence in Brazil.

For the reader, ethnographic qualitative research methodology is aimed at exploring social and cultural phenomena that includes the relevant history, human terrain, political climate, and habitat of a society. Typically, an ethnographic study intends to describe the culture of a people from data collection sources derived from personal experience, direct observations, informant interviews, and analysis of popular written communications.

This research also provides a sociological intelligence assessment that is useful to both intelligence agencies and military analysts concerning the social stratification or class systems, the influence of religious doctrine and educational institutions, and the social dynamics of a population [5]. Military sociological concepts are essential to understanding a region's political and social stability, conventional (standing Army) and unconventional (insurgent or guerrilla force) military capability, the nation's resistance to occupation forces, and correct foreign policy $[5,6]$.

Failure to employ sociological intelligence collection assets is detrimental in developing an invasion plan, starting a revolutionary movement, creating a counter-insurgency strategy, or forming a political-military strategic partnership with desired target country [5]. Any counter-insurgency strategy that does utilize sociological intelligence analysis into the military or political planning process will only assure a total mission failure that will assess great costs in "blood and treasure" for both the intervening country and the country of desired intervention [7]. Sociological intelligence can also provide insights to countries plagued with insurgencies such as in Iraq and narco-terrorism in Mexico [8,9].

\section{Open Source Sociological Intelligence on Islamic Movements in Brazil}

According to the Brazilian census of 2010, there were 35,167 Muslims living in the country, many concentrated in cities of São Paulo and Foz do Iguazu. Recent Shi'ite Islamic immigrants have gravitated to the Muslim communities in São Paulo, Curitiba, and Foz do Iguazu. To date there are more than thirty-six mosques, Islamic religious centers, and Islamic associations in Brazil.

A recent trend is the increase of religious conversions to Islam among non-Arab citizens. A recent Muslim source estimated that there are close to 10,000 Muslim converts living in Brazil. During the past 30 years, Islam has become increasingly noticeable in Brazilian society by the building of not only mosques, but also libraries, art centers, Islamic schools, and publishing newspapers. In fact, the city of Sao Paulo along "State Avenue" one will find the "Muslim Benevolence Society" home to largest Mosque in Brazil (Personal site visit conducted by the author on August 25" ${ }^{\text {th }}$ 2013).

\section{Open Source Sociological Intelligence on Al-Qaeda in Brazil}

Derived from open intelligence sources, various newspaper sources in Brazil note Al Qaeda operatives have been planning attacks, raising money, and recruiting followers in their country [10]. Brazilians contend the isolated and uninhabited areas in the north of the country enable Al-Qaeda in Brazil (AQB) to train mostly in secret.

Derived from personal interviews, one Brazilian contended that a rigid class structure with rampant poverty, widespread government corruption, evangelical Christian cults, make conditions suitable for an extremist religious theology to quickly spread in Brazil (Personal Interview taken in Rio de Janeiro: August 16 ${ }^{\text {th }}, 2013$ ).

One Brazilian described a long and current history of "evangelical" Christian cults present in Brazil. The cults practice strict religious indoctrination using brainwashing techniques, proclamation of fundamentalist religious rhetoric, and the presentation of radical and distorted biblical interpretations. The Brazilian articulated the true purpose of "evangelical" religion was primarily focused on the financial enrichment of the Christian cult leader (Personal Interview taken in São Paulo: August 6 ${ }^{\text {th }}$, 2013).

In the past and present, several high profile lieutenants of Al Qaeda such as Khaled Hussein Ali, have been active in Brazil spreading anti-American and Israeli propaganda for years [11].

Specifically, the Brazilian police investigation found videos and text messages directed at Al Qaeda followers. The suspect also created computer generated "spam" e-mail accounts that promoted hatred of Jews and blacks.

Brazil is home to one of the largest Arab populations outside of the Middle East, with most living in São Paulo and in Fóz do Iguaçu, a hotbed of cocaine smuggling in the so-called Tri-border region near Argentina and Paraguay. The tri-border region is said to have some 12,000 residents of Arab origin, most in the city of Fóz do Iguaçu. The area already has active weapons trafficking 
for Brazil's numerous criminal cartels [12]. One Brazilian felt most of these cartels already possess "state of the art" weapons that easily "outgun" the Brazilian police and military throughout the country, especially in Brazil's dangerous "favelas" slum areas (Personal Interview taken in Rio de Janeiro: August 13 ${ }^{\text {th }}, 2013$ ).

A specific example of how overwhelmed the police are is easily seen in a Sao Paulo area dubbed "Cracolandia” or "Crack Land." [13] One Brazilian described an entire district of a population estimated to be in the thousands of crack-cocaine addicts. A visit to "Cracolandia" of Sao Paulo noted a graffiti ridden lawless haven of drug lords, crack-addicts, and abandoned children who are socially destined to follow the same fate as their parents. Brazilian officials have formally acknowledged they are dealing with a "crack epidemic" and increased drug related violence. This is in spite of the fact that small amounts of marijuana for personal use are completely legal in Brazil.

Brazilians interviewed stated the crack social problem is only getting worse. Brazilian media sources note sustained crack-cocaine addiction is due to the fact that "crack" is cheap and readily available. Crack-cocaine addiction has also devastated other major cities in the United States from Miami, Florida fronting the Atlantic Ocean to Honolulu, Hawaii centered in the Pacific Ocean [14-16].

In addition to the Brazilian city of Sao Paulo, numerous "Cracolandias" have appeared all over the country within in the last decade to include a "Cracolandia" in Brazil's most popular tourist destination of Rio de Janeiro. As early as 2011, President Dilma Rousseff allocated $\$ 1.9$ billion dollars from Brazil's federal budget to battle crack-cocaine. Most of the expenditures were earmarked for drug treatment and education for the estimated 1.5 million crack-addicts in the country. A comparison to handling the crack-cocaine epidemic to handling Al-Qaeda in Brazil (AQB) takes a simple analysis of sociological intelligence:

"If one thinks the Brazilian Federal Police can suppress extremely dedicated and highly skilled Al-Qaeda operatives trained in advanced terrorism while in the mountains of Afghanistan and now embedded into Brazilian communities, one should think again."

In addition to rampant crack-addiction and alcoholism, addiction to gambling also enters the picture. Brazil's looming, seemingly benign, but highly addictive and extremely illegal gambling problem centers on the country's numerous "bingo" game parlors. Similar to the financial losses and Chinese street gang associated "Mahjong" parlors have been noted in America's numerous "Chinatowns" from New York to Hawaii [17]. Although, the Chinese "Mahjong" game often does provide hours of entertainment, however in reality it plunders and squanders the "life savings" of many immigrant ethnic Chinese. Problem gambling associated with illegal "bingo games" also plagues many Brazilians.

\section{Islamic Extremists in Brazil}

Global intelligence agencies and non-governmental organization (NGOs) watch groups have been concerned for years that the triborder region could be a fundraising center for the Islamic extremists groups of Lebanon's Hezbollah (Arabic: Party of God) and Palestinian Hamas (Arabic: Islamic Resistance Movement) [18-20]. Both of these groups practice radical Islamic fundamentalism that utilizes measures of terrorist skyjacking, suicide bombing, and the manufacture of deadly improvised explosive devices (IEDs). However, Brazil has not passed any specific anti-terrorism legislation, does not recognize Hezbollah or Hamas as terrorist groups, and disbanded the Federal Police's anti-terrorism service in 2009 [11].

Analysts agree that Hezbollah themed "Islamic Resistance in Lebanon" started its infiltration of Latin America in the mid-1980's, establishing its first major stronghold in the tri-border - a relatively lawless region along the frontiers of Argentina, Brazil, and Paraguay [21]. From this base deep in the heart of South America, Hezbollah set up illicit enterprises to fund its operations in the Middle East and elsewhere [12]. Current types of criminal activities discussed in the tri-border region by Brazilian sources include money-laundering, counterfeiting brand name clothing and lingerie (Victoria's Secret), women's body lotion and facial cream, jewelry (watches), movie DVD piracy and computer programs, and drug trafficking - primarily cocaine.

Brazilian police authorities in São Paulo also detained an Arab national who ran a website whose forum included anti-American rhetoric written in Arabic. The man is considered a key player in Al Qaeda's social media propaganda campaign [22].

In addition to shutting down the extremist website, Brazilian police also seized his computers to determine any relation to terrorist networks. Brazilian prosecutors described the content of the website as "deplorable" and filled with messages about the hatred of Americans and religious intolerance [22].

Police officials were frustrated because the suspect had to be released in 21 days because he has a fixed residence in Brazil and in the country legally. Police officials contend the individual may be charged under Brazilian laws that criminalized the electronic promotion of racial intolerance [22]. When pressed for more information, U.S. officials referred all questions about the matter to Brazilian authorities.

Police officials have levied serious accusations as to how Islamic terrorists have infiltrated the country of Brazil. The Director of Intelligence for Brazil's Federal Police, Daniel Lorenz, laid out a sinister scheme of radical Islamic terrorist subversion into Brazil: (1) religious extremists used Brazil as a "stop over" to avoid detection in Latin America's largest country and the over populated 
city of Sao Paulo, (2) married prostitutes and adopted their children to secure legal residency in the country, (3) the seductive use of Islamic rhetoric promoting a better life to Brazil's poor, and (4) once entrenched on Brazil soil, Islamic terrorists began to plan to attack targets abroad.

Another problem expressed during an interview with a Brazilian national from Sao Paulo is a proud denial that no terrorism exists in their country. Even the Brazilian Legislature does not contemplate the crime of terrorism according former Minister of Justice Taro Genro. This proud denial of "non-existent" terrorism by the Brazilian government has enabled Al-Qaeda in Brazil (AQB) operatives to spread slowly into many parts of the country - especially the city of Sao Paulo.

For example, one suspected Al-Qaeda member had two houses in Sao Paulo and coordinated a so called "social media battalion" of jihadists [20]. Initially, the social media themes generated from Sao Paulo merely "proselytized" or "preached the goals" of Al-Qaeda. However, the internet social media themes then transformed into a "social media websites" for recruitment, logistics, communication training, and "calls for action" to strike targets.

However, Brazilian police officials express a slight disinterest in the radical Islamic movement in Brazil because they contend AlQaeda has no intent to attack their host country. This lack of concern was derived from the following statement of the Police Chief Daniel Lorenz:

"We have the perception that these foreigners in Brazil are evidently not executing extremist action in this country, but starting recruiting programs, support training, logistics, and reconnaissance for terrorist actions outside the country. They utilize our country as a peaceful place. From it, they leave to help these organizations."

The website "discoveringislam.org" features Internet videos of Brazilians from traditional Catholic faith who have recently converted to Islam. The trendy online videos show a wide range of convert testimonials, from a young Brazilian girl raised Catholic to former Evangelical pastor, both espousing commitment to their newfound Islamic faith [23]. Another news media clip highlights how nineteen individuals converted to Islam during Brazil's hosting of the World Cup international soccer tournament [24].

However, a more radical transformation from a liberal Catholic city to rigid Islamic society in Brazil was expressed by the comments of this 22-year-old Brazilian national about what she observed in Fóz do Iguaçu:

"I didn't feel like I was in Brazil. I saw women dressed in strange clothing covered from head to toe. Many spoke a language I had never heard before in Brazil. It was as if I was in another country, in a different culture - even the buildings (architecture) were different. I also felt that I was not welcomed there since I was an Evangelical and told not to discuss Jesus in the Mosque. I really felt like a foreigner in my own country (Personal Interview taken in Rio de Janeiro: August 14 ${ }^{\text {th }}, 2013$ ).”

It is unknown if the thousands of religious converts to Islam within Brazil occurred from a mere enlightenment of the Islamic religion, a distain of Catholic doctrine, or simply a rejection of Brazilian culture. However, rapid "conversions" to Islam is a concept often referred to as "radicalization," which generally lays the foundation for an Islamic extremist theology conducive to terrorist actions [25].

Al-Qaeda operatives have been successful in radicalizing "lone wolf" attacks in the United States. Most notable "Al-Qaeda radicalizations" include Army Officer and Fort Hood, Texas mass shooter Nidal Hassan in 2009 [26] and Ivy League "Dartmouth" American college student in Massachusetts who bombed the 2013 Boston Marathon [27]. A debatable "indoctrination" process is occurring in Brazil was derived from the following statement:

"As one young women explained - "I entered the Mosque in Foz de Iguaçu as a tourist, my friends and I were required to put on the traditional Islamic clothing that showed only my face. At first, I thought it was funny, but now I am not so sure" (Personal Interview taken in Rio de Janeiro: August 14 $\left.4^{\text {th }}, 2013\right)$."

Brazilian government officials contend a population of 35,000 practicing Muslims with a few misguided Islamic religious zealots is no threat to their country. However, this is short sighted considering the greatest terrorist attack against the United States on September $11^{\text {th, }} 2001$ at the New York World Trade Center was committed by only nineteen Al-Qaeda operatives. These nineteen individuals killed 3000, injured more than 6000, and caused more than $\$ 105$ billion dollars in damages. Not to mention causing serious re-analysis of the United States as a global superpower or merely a "sitting duck" and a failed capitalist regime in decline.

Brazil has repeatedly denied terrorist activity within the republic, despite the fact that Hezbollah has major cells operating in the country and even some Al Qaeda operatives [28]. Although Hezbollah and Al-Qaeda come from different, and hostile, branches of Islam, this is not an obstacle for the two organizations to form alliances of convenience seeking to reach common goals against a "common" adversary, the United States [29]. The infamous "tri-border" region has traits of organized crime and lawlessness that makes it particularly inviting to generate revenue in order to finance terrorist activities.

Most Muslims in the Americas are Sunnis, in line with their proportion in the world's population. In contrast, the Shiites constitute almost half of all the Muslim residents of Foz do Iguaçu, the Brazilian city with the largest Islamic community in the Triple Frontier [29]. The concern is that willing elements from each, Al-Qaeda and Hezbollah, could temporarily unite for mutual benefit and form a common front in the Americas against the United States, the perceived common enemy [30]. 
In comparison, Brazil's neighboring country of Argentina has already experienced the same trend of Islamic extremists in the 1990s. Two incidents that highlight the danger of radical Islam in Latin America were the murders of twenty-nine by a suicidehomicide bombing at the Israeli Embassy in Buenos Aires in 1992 and the killing of ninety-five at a Jewish Community Center bombing in 1994 [19].

\section{The Potential for Marxist-Islamic Terrorism in Brazil}

For the social classes of Brazil, a belief that radical social change is only achieved by terrorist violence is a common thread in Brazilian history. Two books that propose radical social change using terrorism are "The Minimanual of the Urban Guerilla" [31] (first published in United States in 1969) and "For the Liberation of Brazil" [32] (first published in France in 1970, but banned within the country shortly after release). Both works are written by assassinated Brazilian Marxist revolutionary Carlos Marighella (1911-1969) and chapters include writing such as: On Rural Guerrilla Warfare, Guerrilla Tactics and Operations, Executions, Sabotage, and Kidnapping.

However, Margihella's works are banned in many countries, never published in Brazilian Portuguese, and rarely, if at all, found in bookstores in Brazil. His works are excluded because they justify radical forms of terrorism to overthrow authoritarian regimes to impose a communist utopia. A rationale to kill the oppressive elements of a government is expressed by the following statement:

"Carlos Margihella: It is necessary for every urban guerilla to keep in mind he can only maintain his existence if he is disposed to kill police and those dedicated to repression and expropriate the wealth of the capitalists, landowners, and imperialists [31]."

As one Brazilian explained Marighella redefined terrorism as the intended action for the revolutionary fighter to topple oppressive regimes by violent actions (Personal Interview taken in Rio de Janeiro: August $13^{\text {th }}, 2013$ ).

The accusation of "violence" or "terrorism" no longer has the negative meaning it used to have. It has acquired new clothing; a new color. It does not divide, it does not discredit; on the contrary, it represents a center of attraction. Today, to be "violent" or a "terrorist" is a quality that ennobles any honorable person, because it is an act worthy of a revolutionary engaged in armed struggle against the shameful military dictatorship and its atrocities [31].

Unlike Argentinean communist revolutionary Ernesto "Che" Guevara who proposed guerrilla action in the countryside, [33] Marighella’s theories envisioned sparking a bloody Marxist revolution with urban guerrilla warfare [34].

Marighella viewed the city as the source of rebellion. Marighella advocated urban guerilla warfare to neutralize and defeat the political institutions in order to create a climate for radical social change.

Inspired by the sociological writings in the Communist Manifesto (1848) [35] and Das Kapital (1867) [36] written by Karl Marx, inspired Marxist Brazilian Carlos Marighella to advocate urban guerilla warfare. Marighella envisioned collapsing the capitalist exploitation produced by the "bourgeois" (French: The affluent), freeing the enslaved "proletariat" (French: The peasants) and creating a classless socialist economy free of poverty that would be guided by a benevolent communist military elite [37].

The Marxist inspired writings in the "Mini-manual of the Urban Guerilla" by Carlos Marighella are considered to be the last of the great literature of revolutionary terrorism in the 20th century [34].

Although assassinated on the streets of Sao Paulo in 1969 by the Brazilian police, his writings in "The Minimanual of the Urban Guerilla" are still highly admired among student revolutionaries in America, Europe and Ireland. Important terrorist groups that have utilized Marighella's methods include the Japanese Red Army, Peru's Shining Path, Germany's Red Army Faction, Direct Action of France, the New World Liberation Front and Weather Underground of the United States [34].

Even though the Brazilian police vendetta was fulfilled against Marighella during the last century, still today remains a small, obscure, unreadable monument marking his assassination site in Sao Paulo (Personal site visit conducted by the author on August $\left.25^{\text {th }}, 2013\right)$. However, a noted nemesis of communist rhetoric, United States President John F. Kennedy once stated "A man may die, nations may rise and fall, but an idea lives on." True to his word noted a current observation while walking in a tattered neighborhood in downtown Sao Paulo. Atop a large community building, appeared large words in gold letters before a red background proudly stating "The Communist Party of Brazil."

A concern derived from this observation is the existence of the beloved memories of Carlos Marighella and his Marxist revolutionary passion and use of terrorism to liberate Brazil could push Brazilian Islamic coverts into committing terrorist acts in the name of Islam. Counterterrorism analysts have argued that virtually all significant "Islamic" terrorist groups, from Al-Qaeda to Hezbollah, Abu Sayyaf to the Palestinian Islamic Jihad, were created or commanded by "former" communists [38].

Further, the most important Taliban leaders such as Abdurrashid Dostum, Shahnawaz Tanai, and Gulbuddin Hikmatyar were all former communists [39]. The terrorists attacks on the Afghani and Pakistani police are specifically taken from the communist revolutionary model put forth in the "The Minimanual of the Urban Guerrilla” authored by Brazilian Communist Party member Carlos Marighella [38]. 
A foundation of Marxist revolutionary thought and the presence of a radical Islamic separatist ideology have already morphed into a significant Marxist-Islamic terrorist group in the Kurdish region of Northern Iraq. The Kurdish Worker's Party or PKK is a well-documented Marxist-Islamic separatist group that has been executing terrorist actions in northern Iraq, southern Turkey and in northern Iran since 1974 [39].

As early as 1995, PKK leader Abdullah Ocalan proclaimed the doctrine of the PKK was Marxist-Islam [40]. Ocalan's religious rhetoric espousing a Marxist-Islamic theology is present in his infamous books of "Prison Writings: The Roots of Civilization" and "Prison Writings Volume II: The PKK and the Kurdish Question in the 21 $1^{\text {st }}$ Century."

Communist extremists, like Ocalan, argue the beliefs of common ownership and equality found within Marxist and Islamic thought would result in a Marxist-Islamic theology to undermine the excessive greed and social inequity subjected onto the proletariat within the capitalist economic system. Based upon this hybrid theology, Ocalan and the PKK have waged a costly forty-year guerrilla war against the Turkish government [41].

Ironically, this Marxist-Islamic theology has resulted in more than 40,000 dead [42] from an ongoing social revolution initially started with the expectation of achieving a utopian world designed by "scientific socialism" [43]. It is important to recognize that does not illustrate the conversion of communists to Islam, but the adaptation of Islam by socialists to fuel Marxist revolutions [38].

To date the imprisoned Ocalan is viewed a as hero and freedom fighter by many ethnic Kurds in Iraq because he advocated autonomy for them. However, the Turkish government calls him a terrorist. The guerilla leader was captured by Turkish commandos in Nairobi, Kenya in 1999 and sentenced to death for treason. US Embassies, such as in Cyprus were also "stoned" by ethnic Kurds who felt the United States had indirectly assisted in Ocalan's capture. However, the Turkish government had petitioned to join the European Union - in which membership prohibits the death penalty, so Ocalan's death sentence was commuted to life in prison [40].

While Ocalan is incarcerated in a Turkish prison on the island of Imrali, attacks in the northern region of Iraq indicate Al-Qaeda is trying to establish a foothold in Kurdish areas of Kirkuk and Sulaymaniyah. Initially in 2004, the Kurdish population was not sympathetic to the Al-Qaeda in Iraq (AQI) insurgency led by Jordanian national Abu Musab al-Zarqawi (Personal interview and site visit conducted by the author: Police Headquarters, Kirkuk, Iraq: 2005). However, the Al-Qaeda Kurdish Brigades (AQKB) headquartered in the Kurdish city of Erbil, formed in 2007. The AQKB's sworn allegiance to the Islamic State of Iraq (ISI) is an alarming trend of militant Islamic activity determined to undermine the Kurdistan Regional Government (KRG) [44].

\section{Conclusion}

Sociology is the study of human social activity ranging from small-group interaction to societal systems and structures [25]. One specific area studied by sociologists is known as social movements. Sociologists define social movements as ongoing group actions. They can be formal or informal groups of individuals or organizations who focus on specific political or social issues. In other words, they carry out, resist or undo a social change.

Traditional terrorist social movements can have elements of (1) fundamentalist religious rhetoric, (2) leftist revolutionary thought, or (3) ideologically fanatical. Examples include, (1) the white supremacist Christian based Aryan Nations formed by Richard Butler in the United States, (2) Joseph Stalin's political purges in the former communist Soviet Union, and (3) Pol Pot's "utopian" genocide in Cambodia [45].

The Al-Qaeda terrorist social movement in Brazil appears to have the elements of (1) an extremist radicalization of pure Islamic thought, (2) a government bureaucracy controlled by strict Sharia Islamic law, and (3) brutally enforced by an Islamic "Jihadist" terrorist network.

However, social movements can be positive or negative. Examples of positive social movements would be the formation of a democratic government derived from George Washington's revolutionary war of 1776 in the American colonies or the Africanborn Muslim slave uprising and revolt of 1835 to abolish slavery in Brazil.

A negative social movement would be a society's acceptance of racist "Jim Crow" segregation laws in the United States or a terrorist religious movement within a society such as the radical cult of "Aum Shinrikyo" or "Supreme Truth" in Japan. In 1995, members of the "Aum Shinrikyo" terrorist cult coordinated the release of deadly sarin gas on five Tokyo subway trains that injured thousands [34]. Still on death row, terrorist cult leader Shoko Asahra explained the mass chaos caused by the gas attack was intended collapse the government of Japan, thus enabling the cult to seize political power with a peaceful "coup d' état" lead by a benevolent spiritual leader [46].

An additional threat is the combination of a "socialist ideology" and a "religious following" found within the communist cult of North Korea. North Korean ruling leaders are frequently regarded as (1) having performed miracles, (2) credited with making advanced scientific discoveries, and (3) having a "birth right" of a mysterious "supernatural" origin [47].

Sociological analysis of social movements identifies the social structures that inhibit or sustain a social movement such as terrorism - in this case the radical Islamic social movement in Brazil. 
Specifically, this research contends that the Al-Qaeda religious extremist theology is a negative social movement in Brazil. Additional factors such as poverty, discrimination, and government inefficiency will permit radical Islamists to multiply and the Al-Qaeda terroristic theology to become a dangerous social movement in Brazil.

Al-Qaeda is now a global network of terrorist operatives extremely proficient in international clandestine terrorist tradecraft, to think otherwise is a dangerous thought pattern. Human terrain analysis and sociological intelligence notes that Al-Qaeda has embedded themselves into benevolent and peaceful Islamic communities of Brazil. Currently, the only threat to Al-Qaeda's existence by the host country is the mere reluctant acknowledgement of the terrorist group's presence. From this understanding, Brazil must develop stronger and deeper relations with Islamic leaders and the Islamic community to undermine the efforts of Al-Qaeda.

For the non-Muslim reader, a cursory analysis of the Holy Koran shows that Islamic extremists mostly fabricate, clearly distort, and intentionally misinterpret religious scriptures to support an Al-Qaeda theology that justifies the assassinations of Muslims, Christians and Jews [48]. This radicalization method is very similar to the Christian Identity extremists in the United States who misuse the Bible to support a theology of white supremacy that justifies the killings of blacks, Jews, and immigrants.

In essence, both social movements are dangerous religious cults that manipulate sacred religious scriptures to "demonize" enemies by labeling them less than fully human. This plainly shows there is no relationship between the Islamic religion and the Al-Qaeda cult. The only relationship between Al-Qaeda and Islam is that Al-Qaeda members merely claim to be Muslims, but in fact practice nothing that has do to with Islam.

Failure to believe that Al-Qaeda is not active in Brazil is a major social problem and intelligence failure. Brazil must develop trust, friendships, and informants in the Islamic community. If not aggressively engaged, Al-Qaeda in Brazil (AQB) operatives will execute their next terrorist attack externally from Brazil or internally against Brazil.

In contrast, the greatest threat to Al-Qaeda is the true Muslim, who understands that Islam is a religion of peace, love, and kindness. Islamic writings found in the Holy Koran do not justify the murder of innocent men, women, and children used by Al-Qaeda terrorists. Those who justify terrorist violence from the writings of the Holy Koran are essentially non-believers, or in reality the true infidels.

\section{References}

1. Byrd RC, Schlesinger AM (2004) The 9/11 Commission report: final report of the National Commission on Terrorist Attacks upon the United States. Br J Gen Pract 54: 966-7.

2. Gunaratna R (2002) Inside Al Qaeda: global network of terror, Columbia University Press, USA.

3. Earle G (2011) Osama bin Laden Dead in US Raid, New York Post, USA.

4. The New York Times (2011) Al-Qaida Says Al-Zawahri Has Succeeded Bin Laden, New York, USA.

5. Malešević S (2010) The sociology of war and violence, Cambridge University Press, USA.

6. Ouellet E (2005) New directions in military sociology, De Sitter Publications, Canada.

7. Sgarlata JR (2012) To know thy enemy: sociological intelligence in strategy development, Biblioscholar, USA.

8. Knowles GJ (2006) Countering Terrorist, Insurgent, and Criminal Organizations: Iraqi Security Forces Joint Coordination Centers. Military Police: The Professional Bulletin of the Military Police Corps 51: 15-6.

9. Knowles GJ (2008) Threat Analysis: Organized Crime and Narco-Terrorism in Northern Mexico. Military Review: The Professional Journal of the United States Army 88: 73-84.

10. Coutinho L (2011) A Rede do Terror no Brasil (The Network of Terror in Brazil), Revista Veja, São Paulo, Brazil.

11. Melamed D (2011) Al-Qaeda cells active in Brazil, magazine says, Jewish Telegraphic Agency, USA.

12. Barillas M (2011) Al-Qaeda Operatives Recruit Members and Plan Attacks in Brazil.

13. Bevins V(2012) In Brazil's cracolandias, roving hordes of lost souls, The nation is grappling with what officials call a crack epidemic, affecting Brazilians of all ages and confounding government efforts to deal with it, Los Angeles Times, USA.

14. Knowles GJ (1996) Dealing Crack Cocaine: A View from the Streets of Honolulu. The FBI Law Enforcement Bulletin, USA.

15. Knowles GJ (1999) Deception, Detection, and Evasion: A Tradecraft Analysis of Honolulu, Hawaii's Street Crack-Cocaine Traffickers. J Crim Justice 27: 443-55.

16. Knowles GJ (1998) Heroin, Crack, and AIDS: Examining Social Change within Honolulu, Hawaii’s Street Sex Trade. Crime Law Soc Change 30: $379-97$.

17. Knowles GJ (1999) Gambling, Drugs, and Sex: New Drug Trends and Addictions in Honolulu, Hawaii, 1998. Sociological Practice 1: 45-69.

18. Harik JP (2004) Hezbolla: the changing face of terrorism, I.B. Tauris, London, UK.

19. Brice A (2013) Iran, Hezbollah mine Latin America for revenue, recruits, analysts say, Cable News Network, USA.

20. Yapp R (2011) Brazil Latest Base for Islamic Extremists, The Daily Telegraph, London, England.

21. Daremblum J (2011) Al Qaeda in Brazil? The Weekly Standard, USA.

22. Clendenning A (2009) Brazil Detains Al-Qaeda Suspect Who Ran Anti-American Web Site, Associated Press, USA.

23. Discovering Islam (2013) Brazilian Coverts: Ex-Pastor from Brazil Reverts to Islam.

24. Allilou A (2014) Brazil: 19 people converted to Islam during World Cup, Morrocco world news.

25. Crossett C, Spitaletta J (2010) Radicalization: Relevant Psychological and Sociological Concepts, John Hopkins University, U.S. Army Asymmetric Warfare Group, USA. 
26. Kime P (2013) Hasan joins five murderers on military's only death row, Army Times, Virginia, USA.

27. Reitman J (2013) The Bomber: How a popular, promising student was failed by his family, fell into Radical Islam and became a monster, Rolling Stone Magazine, USA.

28. Fleischman L (2015) In Latin America, radical Islamic presence flourishes while key countries downplay the threat, Center for Security policy.

29. Daremblum J (2011) Iran and Latin America, Security and Foreign Affairs: The Hudson Institute, USA.

30. Fowler J (2016) Al-Qaeda, Hezbollah, and Hamas all Active in South America, In Homeland Security, USA.

31. Marighella C (1969) The Minimanual of the Urban Guerilla, Abraham Guillen Press, Canada.

32. Marighella C (1974) For the Liberation of Brazil, Penguin Books, New York.

33. Guevara C (1961) Guerrilla Warfare, Skyhorse Publishing, New York, USA.

34. White J (2006) Chapter 12 in Terrorism and Homeland Security ( $5^{\text {th }}$ Edn), Cengage Learning, USA.

35. Marx K, Engels F (1848) The Communist Manifesto: Complete Version, Progress publishers, Moscow,USSR.

36. Marx K (1967) Das Kapital: Critique of the Political Economy, Progress Publishers, Moscow, USSR.

37. Time Magazine (1960) Communism's Western Beach Head - Cuba: Castro’s Brain, USA.

38. William JF (2009) Terrorist Targeting of Police, The new America.

39. Leitzinger A (2002) The Roots of Islamic Terrorism, The Eurasian Politician.

40. White J (2006) Chapter 11 in Terrorism and Homeland Security ( $5^{\text {th }}$ Edn), Cengage Learning, USA.

41. Okur Y (2016) Over 1,100 die in PKK attacks in Turkey since July 2015, Turkey.

42. Safak Y( 2015) Nearly 7,000 civilians killed by PKK in 31 years, Turkey.

43. Korn DA (1995) Interview with Abdullah Ocalan, Turkey.

44. Khalil L (2007) The Kurdistan Brigades: Al-Qaeda’s Kurdish Henchman, Terrorism Focus: 4.

45. Inside Pol Pot's Secret Prison. USA: The History Channel, 2002, USA.

46. Walsh J (1995) Cult of Doom: A poison-gas attack triggers fears about extremists using homemade weapons of mass death, Time Magazine, USA.

47. Harden B (2013) Escape from Camp 14: one man's remarkable odyssey from North Korea to freedom in the West, Penguin Books, London, England.

48. Marmaduke P (1996) The Glorious Qurân (2 ${ }^{\text {nd }}$ Edn) Tahrike Tarsile Qur'an, Turkey.

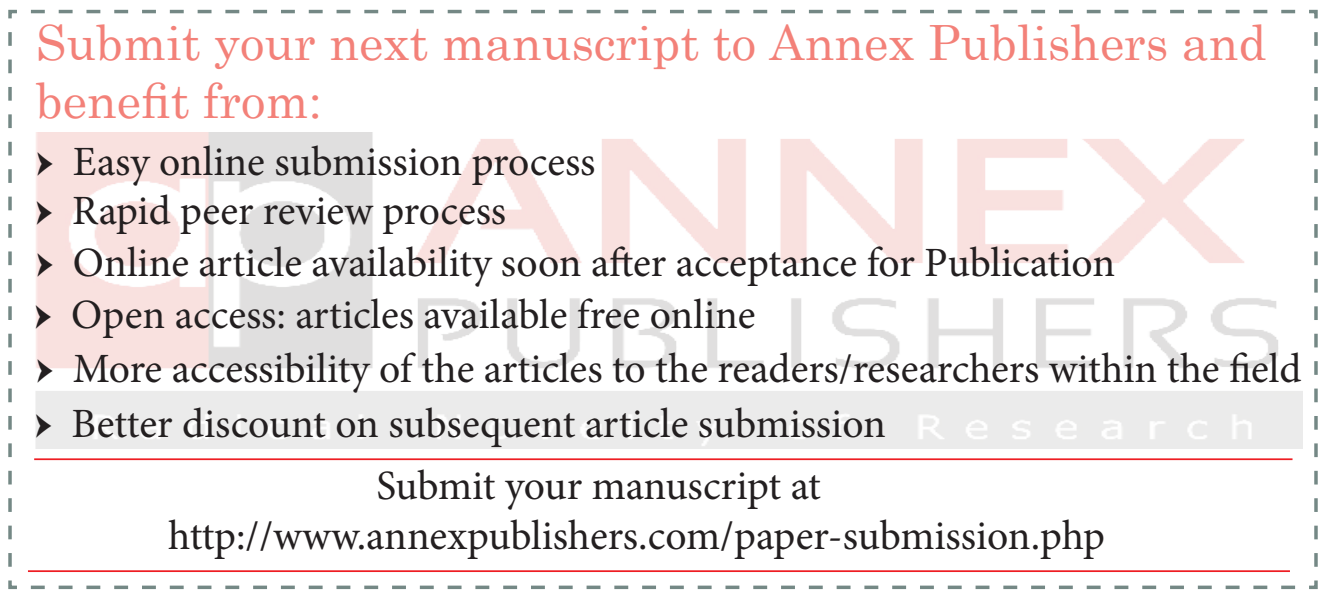

